\section{Trening gjør mester}

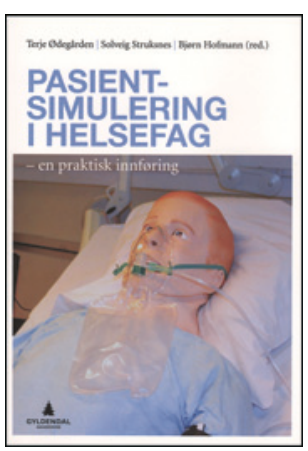

Terje Ødegården, Solveig Struksnes,

Bjørn Hofmann, red.

Pasientsimulering i helsefag

En praktisk innføring. $117 \mathrm{~s}$, tab, ill. Oslo:

Gyldendal Akademisk, 2015. Pris NOK 290

ISBN 978-82-05-46444-5

Bidragsyterne gir en kortfattet og systematisk innføring i bruk av simulatorer $\mathrm{i}$ undervisningen av sykepleiere og radiografer, og boken omhandler derfor ikke treningssimulatorer for avanserte intervensjonsprosedyrer eller kirurgiske teknikker. Den gir imidlertid en god oversikt over prinsippene for simulatortrening og inneholder flere praktiske tips som er nyttig for all simulatortrening av helsearbeidere, også medisinstudenter og leger.

Simulatortrening og testing er en viktig del av sertifiseringen av flere yrkesgrupper, som piloter og førere av skip osv. Simulatortrening brukes i dag systematisk i sykepleieutdanning, radiografutdanning, i medisinstudiet og i trening av alle helsefaglige yrkesgrupper.

Simulering kan brukes for å trene en utøver i en spesifikk ferdighet. Da er det vanligvis nok med en enkel modell av et organ eller en kroppsdel. Treningsdukker og pasientsimulatorer kommer i dag i alle varianter, fra enkle dukker til avanserte elektroniske simulatorer, der man kan trene på spesielle scenarioer og teamkommunikasjon, og der dukkens vitale funksjoner kan endres ut fra hva studentene gjør av behandling og pleie. Disse simulatorene har vist seg nyttige når man trener på samhandling og teamarbeid i situasjoner der flere helsearbeidere arbeider sammen om pasienten.

For å få optimalt utbytte av simuleringen kreves det at simuleringen inngår som en del av et helhetlig undervisningsopplegg. Selve simuleringen må legges opp systematisk med forberedelser, undervisning om simulatoren, selve simuleringen og en debriefing.

Boken har et nyttig kapittel om hvordan man kan sminke dukken for å simulere spesielle skader. Den beskriver også de ulike rollene instruktørene har ved gjennomføringen av mer avanserte simuleringer. Det er også nyttige tips om gjennomføring av briefing og debriefing.

Dette er en lett tilgjengelig og velskrevet bok for alle som vil bruke simulatorer i treningen av helsearbeidere.

\section{Erik Fosse}

Avdelingsleder, Intervensjonssenteret

Oslo universitetssykehus

\section{God lærebok om pårørende}

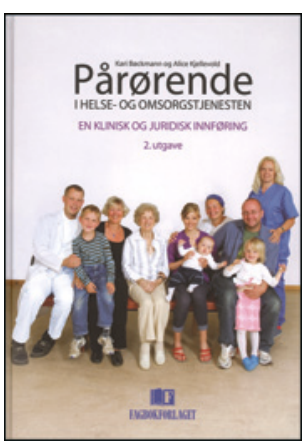

Kari Bøckmann, Alice Kjellevold

Pårørende i helse- og omsorgstjenesten

En klinisk og juridisk innføring. 2. utg. 428 s,

ill. Bergen: Fagbokforlaget, 2015.

Pris NOK 549

ISBN 978-82-450-1620-8

Det er økende oppmerksomhet om pårørendes behov og rettigheter i møtet med sykdom og helsetjeneste. Psykologen Kari Bøckmann og juristen Alice Kjellevold har gitt ut en revidert og oppdatert versjon av en lærebok om kliniske og juridiske aspekter vedrørende pårørendes situasjon. Den ble første gang utgitt i 2010. Målgruppen er studenter $i$ helsesektoren, helsepersonell, pårørende selv og organisasjoner for pårørende.

Boken er inndelt i 11 kapitler som omhandler generelle og spesifikke forhold knyttet til pårørendes situasjon og rettigheter. Pårørendes utfordringer med både somatiske og psykiatriske sykdomstilstander blir gjennomgått. Et kapittel er viet foresattes situasjon ved sykdom hos barn og ungdom, og et kapittel omhandler barn og ungdom som pårørende. Det teoretiske stoffet underbygges med gode kasuistikker og sitater som levendegjør innholdet. Alle kapitlene sammenfattes i oppsummeringer, og det er fyldige referanser til relevant litteratur, offentlige dokumenter og gjeldende lover og forskrifter. Det er inkludert en oversikt over norske brukerorganisasjoner og et stikkordregister.

Forfatterne er opptatt av at helsepersonell skal yte kunnskapsbasert klinisk praksis overfor pårørende, og de presenterer hovedtrekk av hva vi per i dag vet om pårørendes behov. Videre er de opptatt av at helsepersonell må ha kjennskap til gjeldende lover og føringer om hvordan pårørende skal involveres, og om hvilke rettigheter de har. Forfatterne skriver innledningsvis: «Å bruke taushetsplikten som argument for ikke å ha kontakt med pårørende er alltid for enkelt, og i mange tilfeller lovstridig.»

Helsedirektoratet ga i 2008 ut veilederen Pårørende - en ressurs (IS-1512), og arbeidet med en ny veileder om pårørende i helse- og omsorgstjenesten er i gang. Man ser en økende forskningsinteresse innen pårørendefeltet. Forfatterne hilser disse initiativene velkommen, og de belyser områder de mener bør videreutvikles. De ser behov for mer kunnskap om hvilke faktorer som beskytter mot helsesvikt hos pårørende, og om hva pårørende faktisk opplever som støttende i møtet med helsepersonell.

Læreboken er godt gjennomarbeidet, lettlest og svært informativ. Jeg anbefaler den som oppslagsverk for alt helsepersonell som er i kontakt med pasienter og deres pårørende.

Tone Skaal

Overlege, Voksenpsykiatrisk avdeling Vinderen

Diakonhjemmet Sykehus 